We are grateful to Dr. G. Plaut, of the North London Blood Supply Depot, for a very large number of samples of $R h$-negative blood; to Dr. W. J. T. Morgan for supplying anti-Le $e^{a}$ and anti-Le $e^{b}$ sera and for testing the saliva of the patient; to Dr. A. E. Mourant for supplies of some of the other rare sera; to Miss Elizabeth Ikin for testing the serum against a panel of human bloods, and confirming that it could not be reacting with any factor within the systems at present recognized; and to Dr. R. R. Race for advice on nomenclature.

$$
\begin{aligned}
& \text { Marie Cutbush } \\
& \text { P. L. Mollison } \\
& \text { Dorothy M. Parkin }
\end{aligned}
$$

Medical Research Council

Blood Transfusion Research Unit,

Postgraduate Medical School,

Ducane Road,

London, W.12

Nov. 23.

${ }^{1}$ Grubb, R., and Morgan, W. T. J., Brit. J. Exper. Path., 30, 198 (1949).

${ }^{2}$ Andresen, P. H., Callender, S., Fisher, R. A., Grubb, R., Morgan W. T. J., Mourant, A. E., Pickles, M. M., and Race, R. R., Nature $168,580(1949)$

\section{Effect of Posterior Pituitary Extract and its Fractions on Renal Electrolyte Excretion}

IT seems to be generally accepted that, in addition to its antidiuretic effect, posterior pituitary extract has a chloruretic action. All workers appear to have found an increase of chloride concentration in the urine; but there is by no means unanimity whether the actual amounts excreted are increased, results varying with the species and experimental conditions (see, for example, Shannon ${ }^{1}$ and O'Connor ${ }^{2}$ ). Furthermore, it is not clear which of the posterior pituitary fractions is mainly responsible for the chloruretic effect, and which ions are excreted with the chloride.

Some observations on this subject have been recently published by O. Schaumann ${ }^{3,4}$, who investigated the action of oxytocin and of vasopressin on the renal excretion of chloride, sodium and potassium ions in rats. We have been engaged in similar experiments. The effect of small doses ( 3 milliunits $/ 100$ gm. s.c.) of 'Pitocin', 'Pitressin' and 'Pituitrin' on the chloride excretion of hydrated rats was first investigated. It was found that the changes in the rate of chloride excretion obtained with 'Pituitrin' and 'Pitressin' coincided-as might have been expected-with the antidiuretic effect. The duration of the antidiuretic effect was therefore used to determine the urine-collecting period.

\begin{tabular}{|c|c|c|c|c|c|c|c|c|}
\hline \multirow[b]{2}{*}{$\begin{array}{l}\text { Controls (micro- } \\
\text { mol./100 gm. } \\
\text { rat/min.) } \\
\text { Ratio 'Pitocin'/ } \\
\text { controls } \\
\text { Ratio 'Pitressin'/ } \\
\text { controls } \\
\text { Ratio 'Pituitrin'/ } \\
\text { controls }\end{array}$} & \multicolumn{2}{|c|}{$\mathrm{K}$} & $a$ & $b$ & $a$ & $b$ & \multicolumn{2}{|c|}{$\begin{array}{l}\text { Unknown } \\
\text { ions } \\
a \stackrel{b}{a}\end{array}$} \\
\hline & $\begin{array}{l}1 \cdot 7 \\
2 \cdot 2\end{array}$ & $\begin{array}{l}1 \cdot 2 \\
1 \cdot 7\end{array}$ & $0 \cdot 24$ & $\begin{array}{l}0.15 \\
1.0 \\
0.7\end{array}$ & $\begin{array}{l}0.19 \\
0.9\end{array}$ & $\begin{array}{l}0 \cdot 13 \\
2 \cdot 1\end{array}$ & $\begin{array}{l}0 \cdot 18 \\
2 \cdot 1 \\
1 \cdot 2\end{array}$ & $\begin{array}{l}0.24 \\
1.4 \\
0.8\end{array}$ \\
\hline
\end{tabular}
The effect of the injection of posterior pituitary extracts on the rate of chloride, sodium and potassium

*, Rats on standard diet. **, Rats on sodium chloride-enriched ion excretion was then studied in rats on standard and sodium chloride-enriched diets.

It will be seen from the accompanying table that both 'Pitocin' and 'Pitressin' increased the rate of potassium excretion, but that 'Pitressin' depressed the excretion of sodium. The effects of the posterior pituitary fractions on chloride excretion appeared to depend on the chloride content of the diet. It will also be noted that the effect of 'Pituitrin' on our rats resembled that of 'Pitocin' rather than that of 'Pitressin'. Schaumann used doses more than ten times greater than ours, and it is difficult, therefore, to relate his results to ours, particularly as even the small doses used by us are known to have marked effects on the glomerular filtration-rate in rats (Dicker and Heller ${ }^{5}$. Our experiments are being extended to determine to what extent changes in glomerulax filtration-rate produced by the posterior pituitary principles bear on renal electrolyte excretion.

\section{H. HexleR}

R. P. STEPHENSON

Department of Pharmacology,

University of Bristol.

$$
\text { Sept. } 3 .
$$

${ }^{1}$ Shannon, J. A., J. Exp. Med., 76, 371 (1942).

${ }^{2} O^{\prime}$ Connor, W. J., Proc. Physiol. Soc., July 1-2 (1949).

Schaumann. O., and Schmidt, I., Arch. Exp. Path. u. Pharmakol. $205,367(1948)$.

'Schaumann, O., Experientia (in the press).

${ }_{5}^{5}$ Dicker, S. E., and Heller, H., J. Physiol., 104, 353 (1946).

\section{Effect of Hæmagglutinating Viruses on the Electrophoretic Mobility of Human Erythrocytes}

THE enzymic activity of influenza viruses, recently characterized in chemical terms for the substrate ovomucin ${ }^{1}$, was first suggested by Hirst ${ }^{2}$, who showed that, following the agglutination of erythrocytes, the virus was eluted spontaneously, leaving the cells inagglutinable by the same strain. Burnet, McCrea and Stone $^{3}$ found that cells from which one strain had become eluted were still agglutinable by certain other strains. The arrangement of influenza $A$ and $B$, mumps and Newcastle disease viruses in the order of their progressive action on cellular receptors was termed the 'receptor gradient'. Elucidation of this unique enzyme-substrate relationship, characterized by the varying extent of interaction, is limited by the qualitative nature of the biological method. The finding of Hanig that, following treatment with the PR8 strain of influenza virus, the electrophoretic mobility of human erythrocytes was markedly reduced, suggested a biophysical approach to the problem.

Human cells were incubated at $37^{\circ} \mathrm{C}$. with excess amounts of the viruses shown in the accompanying table for periods sufficient to allow the reaction to proceed to completion, as judged by changes in agglutinability and electrophoretic mobility. Except in the case of Newcastle disease and mumps viruses, cells were stabilized with immune serum before testing ${ }^{3}$ Microelectrophoresis was carried out at $25^{\circ} \mathrm{C}$. in an $M / 15$ phosphate buffer of $p \mathrm{H} 7.35$ after the method of Moyer ${ }^{5}$.

The results show that with each virus the loss of agglutinability is accompanied by a reduction in mobility, corresponding, in most cases, with the position of the virus in the receptor gradient. New- 